\title{
Erratum to: An ancient genome duplication contributed to the abundance of metabolic genes in the moss Physcomitrella patens
}

Stefan A. Rensing ${ }^{1 *}$, Julia Ick', Jeffrey A. Fawcett ${ }^{2,3}$, Daniel Lang ${ }^{1}$, Andreas Zimmer ${ }^{1}$, Yves Van de Peer ${ }^{2,3}$ and Ralf Reski ${ }^{1}$

\section{Erratum}

The author's would like to make the readers aware that the original version of this article [1] unfortunately contained a mistake. The following text published in the "Results and Discussion" section was supplied as follows:

"If we assume that the genome duplication indeed took place about 45 MYA (average of the peak in Fig. 1), and we assume that genes duplicated at that time have an average KS value of 0.85 (see Fig. 1), we can infer the rate of synonymous substitutions by simply dividing 0.85 by $45 \mathrm{MY}$. This gives us a rate of 1.9 synonymous substitutions per synonymous site per year, ..."

However this should read:

"If we assume that the genome duplication indeed took place about 45 MYA (average of the peak in Fig. 1), and we assume that genes duplicated at that time have an average KS value of 0.85 (see Fig. 1), we can infer the rate of synonymous substitutions by simply dividing 0.85 by two times $45 \mathrm{MY}$ (two times since Ks accumlate independently in the paralogs after the duplication). This gives us a rate of 9.4E-09 synonymous substitutions per synonymous site per year, ..."

\section{Author details}

'Plant Biotechnology, Faculty of Biology, University of Freiburg, Schaenzlestr. 1, D-79104 Freiburg, Germany. ${ }^{2}$ Department of Plant Systems Biology, VIB, B-9052 Ghent, Belgium. ${ }^{3}$ Bioinformatics and Evolutionary Genomics, Department of Molecular Genetics, Ghent University, Technologiepark 927, B-9052 Ghent, Belgium.
Received: 15 July 2016 Accepted: 10 August 2016

Published online: 08 September 2016

\section{Reference}

1. Rensing SA, Ick J, Fawcett JA, Lang D, Zimmer A, Van de Peer Y, Reski R. An ancient genome duplication contributed to the abundance of metabolic genes in the moss Physcomitrella patens. BMC Evol Biol. 2007;7:130. doi:10. 1186/1471-2148-7-130

Submit your next manuscript to BioMed Central and we will help you at every step:

- We accept pre-submission inquiries

- Our selector tool helps you to find the most relevant journal

- We provide round the clock customer support

- Convenient online submission

- Thorough peer review

- Inclusion in PubMed and all major indexing services

- Maximum visibility for your research

Submit your manuscript at www.biomedcentral.com/submit
${ }^{1}$ Plant Biotechnology, Faculty of Biology, University of Freiburg, Schaenzlestr. 1, D-79104 Freiburg, Germany

Full list of author information is available at the end of the article (c) 2016 The Author(s). Open Access This article is distributed under the terms of the Creative Commons Attribution 4.0 International License (http://creativecommons.org/licenses/by/4.0/), which permits unrestricted use, distribution, and reproduction in any medium, provided you give appropriate credit to the original author(s) and the source, provide a link to the Creative Commons license, and indicate if changes were made. The Creative Commons Public Domain Dedication waiver (http://creativecommons.org/publicdomain/zero/1.0/ applies to the data made available in this article, unless otherwise stated. 